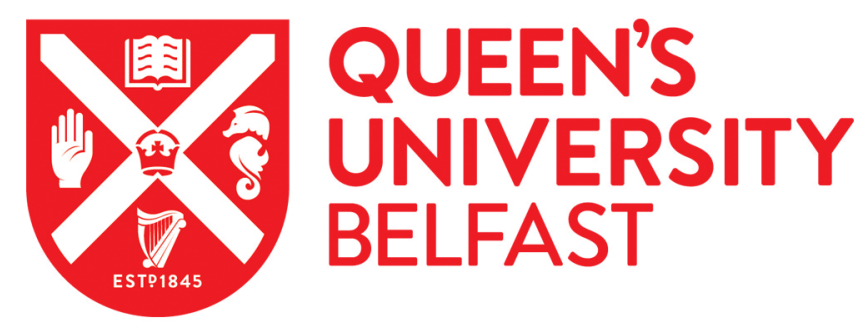

\title{
Photocatalytic removal of the cyanobacterium Microcystis aeruginosa PCC7813 and four microcystins by TiO2 coated porous glass beads with UV-LED irradiation
}

Pestana, C. J., Noronha, J. P., Hui, J., Edwards, C., Gunaratne, H. Q. N., Irvine, J. T. S., Robertson, P., CapeloNeto, J., \& Lawton, L. (2020). Photocatalytic removal of the cyanobacterium Microcystis aeruginosa PCC7813 and four microcystins by TiO2 coated porous glass beads with UV-LED irradiation. Science of the Total Environment, 745, [141154]. https://doi.org/10.1016/j.scitotenv.2020.141154

\section{Published in:}

Science of the Total Environment

\section{Document Version:}

Peer reviewed version

Queen's University Belfast - Research Portal:

Link to publication record in Queen's University Belfast Research Portal

\author{
Publisher rights \\ (C) 2020 Elsevier Ltd. \\ This manuscript is distributed under a Creative Commons Attribution-NonCommercial-NoDerivs License \\ (https://creativecommons.org/licenses/by-nc-nd/4.0/), which permits distribution and reproduction for non-commercial purposes, provided the \\ author and source are cited.
}

\section{General rights}

Copyright for the publications made accessible via the Queen's University Belfast Research Portal is retained by the author(s) and / or other copyright owners and it is a condition of accessing these publications that users recognise and abide by the legal requirements associated with these rights.

Take down policy

The Research Portal is Queen's institutional repository that provides access to Queen's research output. Every effort has been made to ensure that content in the Research Portal does not infringe any person's rights, or applicable UK laws. If you discover content in the Research Portal that you believe breaches copyright or violates any law, please contact openaccess@qub.ac.uk. 
1 Photocatalytic removal of the cyanobacterium Microcystis aeruginosa PCC7813 and four microcystins by $\mathrm{TiO}_{2}$ coated porous glass beads with

\section{UV-LED irradiation}

4

5 Carlos J. Pestana ${ }^{a *}$, Jolita Portela Noronha, ${ }^{a, b}$, Jianing Huic, Christine Edwards ${ }^{a}, \mathrm{H}$.

Q. Nimal Gunaratne ${ }^{d}$, John T.S. Irvine ${ }^{c}$, Peter K.J. Robertsond, José Capelo-

$7 \quad$ Neto $^{b}$, Linda A. Lawton ${ }^{a}$

8

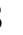

a School of Pharmacy and Life Sciences, Robert Gordon University, Aberdeen, United Kingdom

b Department of Hydraulic and Environmental Engineering, Federal University of Ceará, Fortaleza, Brazil

c School of Chemistry, University of St. Andrews, St. Andrews, United Kingdom

d School of Chemistry and Chemical Engineering, Queen's University, Belfast, United Kingdom

*Corresponding author: c.pestana@rgu.ac.uk

Keywords: Cyanobacteria, Photocatalysis, Cyanotoxins, Water Treatment, Titanium Dioxide, UV-LED

\section{Highlights}

- Photocatalytic inhibition of M. aeruginosa PCC7813 $\left(7.6 \times 10^{5}\right.$ cells $\left.\mathrm{mL}^{-1} \mathrm{~d}^{-1}\right)$

- $74 \%$ removal of four microcystins (intra- and extracellular)

- Porous glass beads made from recycled glass used as catalyst support

- UV irradiance supplied by low energy UV (365 nm) emitting LEDs 

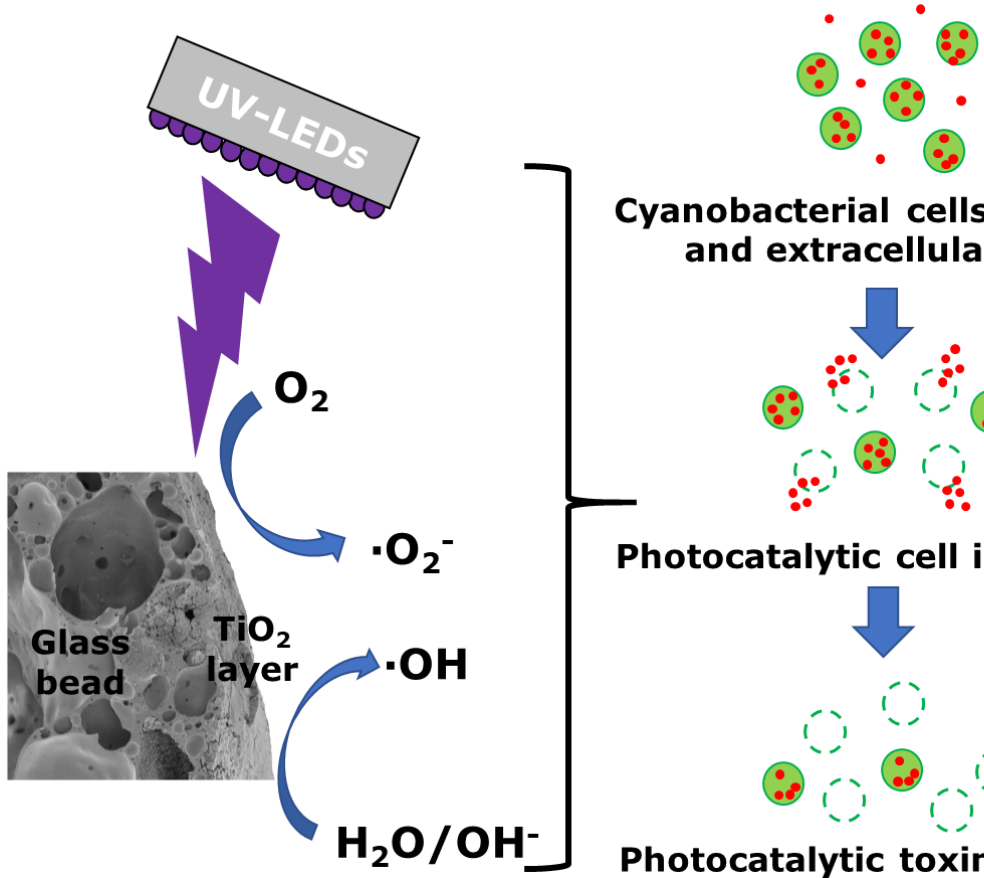

Cyanobacterial cells with intraand extracellular toxins

Intact M. aeruginosa cell Microcystins

Abstract

Cyanobacteria and their toxic secondary metabolites are a challenge in water treatment due to increased biomass and dissolved metabolites in the raw water.

Retrofitting existing water treatment infrastructure is prohibitively expensive or unfeasible, hence 'in-reservoir' treatment options are being explored. In the current study, a treatment system was able to photocatalytically inhibit the growth of Microcystis aeruginosa and remove released microcystins by photocatalysis using titanium dioxide coated, porous foamed glass beads and UV-LEDs (365 nm). A 35\% reduction of M. aeruginosa PCC7813 cell density compared to control samples was achieved in seven days. As a function of cell removal, intracellular microcystins (microcystin-LR, -LY, -LW, and -LF) were removed by $49 \%$ from 0.69 to $0.35 \mu \mathrm{g} \mathrm{mL}-1$ in seven days. Microcystins that leaked into the surrounding water from compromised cells were completely 
removed by photocatalysis. The findings of the current study demonstrate the feasibility of an in-reservoir treatment unit applying low cost UV-LEDs and porous foamed beads made from recycled glass coated with titanium dioxide as a means to control cyanobacteria and their toxins before they can reach the water treatment plant.

\section{Introduction}

Cyanobacteria are well known to form blooms in nutrient-rich waters, including drinking water reservoirs. High cell densities challenge water treatment systems by reducing the run time of filters leading to an increased demand of treatment chemicals such as coagulants and disinfectants (De Julio et al., 2010). This problem is often further acerbated by the release of toxic and/or noxious metabolites produced by the cyanobacteria, further challenging water treatment plant operators and decreasing water security (Chow et al., 1999; Drikas et al., 2001; Velzeboer et al., 1995). The most commonly reported cyanobacterial toxic metabolites are the microcystins. To date at least 247 microcystin congeners have been described (Spoof and Catherine, 2017). The toxicity of microcystins has been recognized as a global issue with the World Health Organisation setting a recommended maximum allowable limit of $1 \mathrm{\mu g} \mathrm{L}^{-1}$ in drinking water (WHO, 2017).

Retro-fitting water treatment plants with improved and advanced technology is often prohibitively expensive and/or physically challenging, hence alternative treatment technologies such as in-reservoir treatment need to be explored. The application of algaecides in the reservoir is the simplest form of in-reservoir treatment but studies have shown the negative effects of this practice, such as toxicity to non-target organisms, development of bacterial resistances, increase 
of potentially toxic/noxious dissolved metabolites and precursors of disinfection by-products (Bishop et al., 2017; García-Villada et al., 2004; Greenfield et al., 2014; Jančula and Maršálek, 2011).

In recent years, advanced oxidation processes, including titanium dioxide $\left(\mathrm{TiO}_{2}\right)$ photocatalysis have been demonstrated to control cyanobacteria and their secondary metabolites. Successful removal of cyanobacterial toxins by $\mathrm{TiO}_{2}$ nanoparticulate photocatalysis have been reported by a number of studies (Cornish et al., 2000; Liu et al., 2009; Pelaez et al., 2011), especially for the elimination of the commonly occurring group of cyanobacterial toxins, the microcystins. One of the most critical technical challenges that has hampered the application of photocatalysis in water treatment is the removal of the nanoparticulate $\mathrm{TiO}_{2}$ materials following treatment. The post treatment recovery of $\mathrm{TiO}_{2}$ is not only a technical challenge but also has ecotoxicological health implications. It has been demonstrated that nanoparticulate $\mathrm{TiO}_{2}$ can bioaccumulate and damage biota (Heinlaan et al., 2008; Wang et al., 2007; Zhu et al., 2010). Further, the application of nanoparticulate $\mathrm{TiO}_{2}$ represents a health hazard to operators if inhaled (Grassian et al., 2007). To avoid the problems of free nanoparticulate $\mathrm{TiO}_{2}$, immobilization of the photocatalyst onto a robust carrier matrix is preferable. Matrices such as activated carbon, metal particles, and glass have been explored, each with inherent advantages and disadvantages (Kinley et al., 2018; Liu et al., 2007; Pestana et al., 2015). Several design parameters have to be considered when applying immobilized $\mathrm{TiO}_{2}$ in a water treatment context. For example, cyanobacteria occupy different positions in the water column, depending on species and time of the day (Varuni et al., 2017). Thus, to ensure maximum efficiency of immobilized $\mathrm{TiO}_{2}$, an even distribution throughout the water column is desirable. Surface floating matrices will not 
reach cyanobacteria deeper in the water column and likewise heavier matrices that sink will miss cyanobacteria higher up in the water column. The use of semi-bouyant foamed glass beads allows for even distribution in the water column. Additionally, the use of low-cost (ca. USD 0.30 per LED), long life (approximately 100,000 working hours), waterproof UV (365 nm) emitting LEDs to activate $\mathrm{TiO}_{2}$ would solve a further technological challenge in the application of this in-situ treatment system, as in the past supplying cost-effective UV irradiation of the required wavelength has been problematic. While in recent years solar light-driven photocatalysis has been explored for the removal of contaminants of emerging concern, including cyanobacteria and their toxins, the application of this technology at scale suffers from drawbacks compared to the use of for example UV-LEDs (Fagan et al., 2016). There are two major drawbacks to this technology, one is the need to modify $\mathrm{TiO}_{2}$ to shift its activity into the visible light range, usually achieved doping with other materials such as noble metals, carbon, or nitrogen (Wang et al., 2017, Fotiou et al., 2013). This would increase the cost of the treatment as additional steps and materials are required in the catalyst preparation. The other drawback of solar light-driven catalysis is that sunlight hours vary across the globe and that it is only available for a maximum of $12 \mathrm{~h}$ per day, thus rendering a purely solar light-driven treatment system inactive overnight. Recently, we have shown the feasibility of such a system for the photocatalytic removal of microcystin-LR (Gunaratne et al., 2020). Applying a similar technology using $\mathrm{TiO}_{2}$ coated porous glass beads and UV-emitting LEDs, we now present a bench scale proof-of-principle inreservoir treatment system that aims to inhibit and eliminate cyanobacteria while simultaneously removing toxins that are released and is energy efficient, thus can be maintained in continuous use to limit cyanobacterial biomass and 
dissolved metabolites entering water treatment plants. It is envisaged that the pre-treatment system operates continuously avoiding the formation of intense blooms and keeping the cyanobacterial biomass at a level that allows the conventional water treatment process to completely remove any remaining cyanobacteria, while at the same ensuring that no dissolved toxins enter the plants that are ill equipped to remove dissolved contaminants, rather than a point treatment used when cell numbers or toxin concentrations exceed national threshold levels.

\section{Materials and Methods}

\subsection{Reagents}

All reagents for the preparation of artificial fresh water (AFW) and cyanobacterial culture medium BG-11 were of reagent grade, obtained from Fisher Scientific (UK), and used as received. Acetonitrile and methanol were of HPLC grade and obtained from Fisher Scientific (UK). Ultrapure water (18.2 M $\Omega$ ) was provided by a PURELAB ${ }^{\odot}$ system (ELGA Veolia, UK). Isoton II Diluent (Beckman Coulter, USA) was used for cell enumeration and biovolume determination.

\subsection{Cyanobacterial cell culture}

M. aeruginosa PCC7813 was originally obtained from the Pasteur Culture Collection (France) and cultured in sterilized BG-11 medium (Stanier et al., 1971), at $22 \pm 1{ }^{\circ} \mathrm{C}$ with a $12 \mathrm{~h} / 12 \mathrm{~h}$ light dark cycle at $20 \mu \mathrm{mol}$ photons $\mathrm{m}^{-2} \mathrm{~s}^{-1}$ under aseptic conditions. M. aeruginosa PCC7813 produces four main microcystin analogues (MC-LR, MC-LY, MC-LW, and MC-LF) and does not contain gas vesicles. 


\subsection{Preparation of $\mathrm{TiO}_{2}$ coated recycled porous glass beads}

151

152

153

154

155

156

157

158

159

160

161

162

163

164

165

166

167

168

169

170

171

172

173

174

175

Porous recycled foamed glass beads (1-4 mm diameter, Poraver, Germany) were sieved to achieve $>2 \mathrm{~mm}$, then washed with acetone, followed by deionised water in a sonication bath (Scientific Laboratory Supplies Ltd., UK) and dried in an oven at $80{ }^{\circ} \mathrm{C}$ for $18 \mathrm{~h}$. After this pre-treatment, beads were coated with titanium dioxide (P25, Rutile/Anatase: 85/15, $99.9 \%, 20 \mathrm{~nm}$ particle size;

Degussa Evonik, Germany) according to a method by Mills et al. (2006) with adaptations. In short, a slurry of P25 and water is prepared into which the pretreated glass beads are submerged. Coated beads are removed from the slurry and allowed to dry, followed by calcination at $550{ }^{\circ} \mathrm{C}$ for $3 \mathrm{~h}$. Each coating procedure deposits approximately $2 \%(\mathrm{w} / \mathrm{w})$ of $\mathrm{TiO}_{2}$ onto the beads. Coatings are repeated until approximately $10 \%(w / w)$ of $\mathrm{TiO}_{2}$ on the beads was achieved. Characterization of the beads and the coating is recorded in the supplementary material (S1 and figure S1).

\subsection{Photocatalytic removal of $M$. aeruginosa PCC7813 and microcystins}

Artificial fresh water (AFW) was used as an experimental matrix in the photocatalysis investigation, and was prepared according to Akkanen and Kukkonen (2003) by dissolving $\mathrm{CaCl}_{2}\left(11.8 \mathrm{mg} \mathrm{L}^{-1}\right), \mathrm{MgSO}_{4}\left(4.9 \mathrm{mg} \mathrm{L}^{-1}\right), \mathrm{NaHCO}_{3}$ (2.6 $\mathrm{mg} \mathrm{L}^{-1}$ ) and $\mathrm{KCl}\left(0.2 \mathrm{mg} \mathrm{L}^{-1}\right)$ in ultrapure water. A three-week-old culture of M. aeruginosa PCC7813 was diluted in AFW to achieve a final cell density of $15 \mathrm{x}$ $10^{6}$ cells $\mathrm{mL}^{-1}$. $\mathrm{TiO}_{2}$ coated beads $\left(700 \mathrm{mg}\right.$, equivalent to $0.2 \%(\mathrm{w} / \mathrm{v}) \mathrm{TiO}_{2}$ ) were placed in glass mesh pods (70 mm x $10 \mathrm{~mm}$ diameter) and placed into $40 \mathrm{~mL}$ glass bottles ( $95 \mathrm{~mm} \times 22 \mathrm{~mm}$ diameter) into which $30 \mathrm{~mL}$ of the cell suspension was added. Three replicates containing the coated beads was irradiated by a $550 \mathrm{~cm}^{2}$ UV-LED panel with 90 individual UV-LEDs (AT 
176 Technologies, UK) providing $2.8 \mu \mathrm{mol}$ photons $\mathrm{m}^{-2} \mathrm{~s}^{-1}\left(2.1 \mathrm{~mW} \mathrm{~s}^{-1}\right)$ at $365 \mathrm{~nm}$

177 and at $100 \mathrm{~mm}$ distance (figure 1 ). Another three replicates, not containing

178 titanium dioxide coated beads was prepared at the same distance from the UV-

179 LEDs functioning as a UV control. While a third set of replicates with $\mathrm{TiO}_{2}$ coated

180 beads was set up outside of the area of irradiation of the UV-LED panel to act as

181 a no-UV control. Typically, in photocatalysis the dark/no-UV control is performed

182 in complete darkness; however, cyanobacteria are photosynthetic organisms

183 that would not survive the duration of the experiment without light, hence this

184 third set of replicates was maintained in ambient light (no UV irradiation at 13

$185 \mu \mathrm{mol} \mathrm{s}{ }^{-1} \mathrm{~m}^{-2}$ cool fluorescent irradiation). To maintain clarity ' $\mathrm{TiO}_{2}$-control' will be

186 used throughout to identify samples that contain $\mathrm{TiO}_{2}$ coated glass beads, but

187 are not exposed to UV irradiation. All samples were sparged at $1.5 \mathrm{~L} \mathrm{~min}^{-1}$ with

188 sterile ambient air. After taking a zero-time sample, each replicate was sampled

189 (1.1 mL) daily.

190 
A

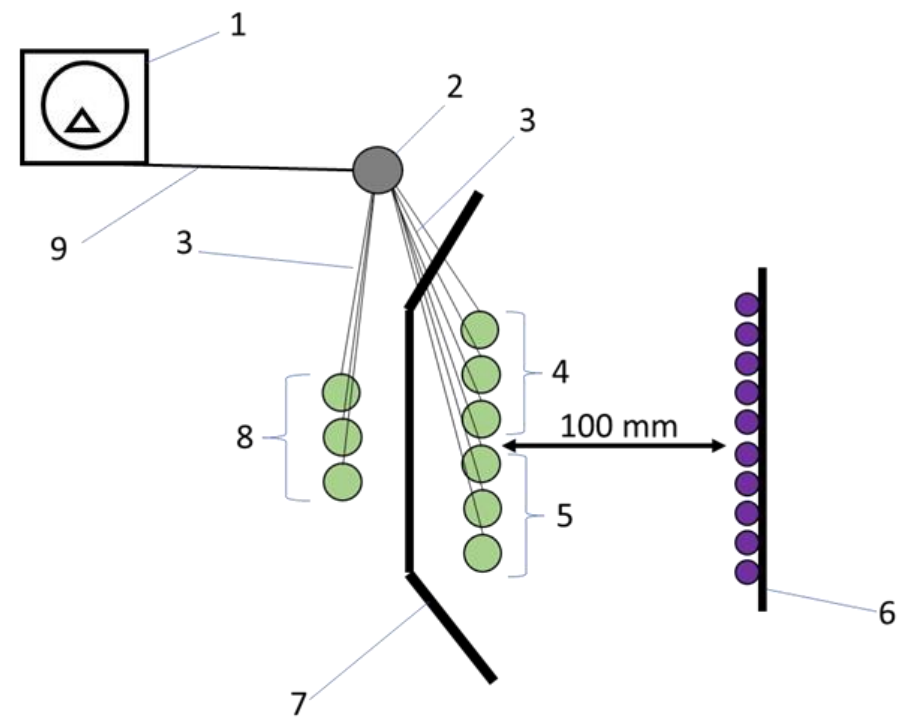

B

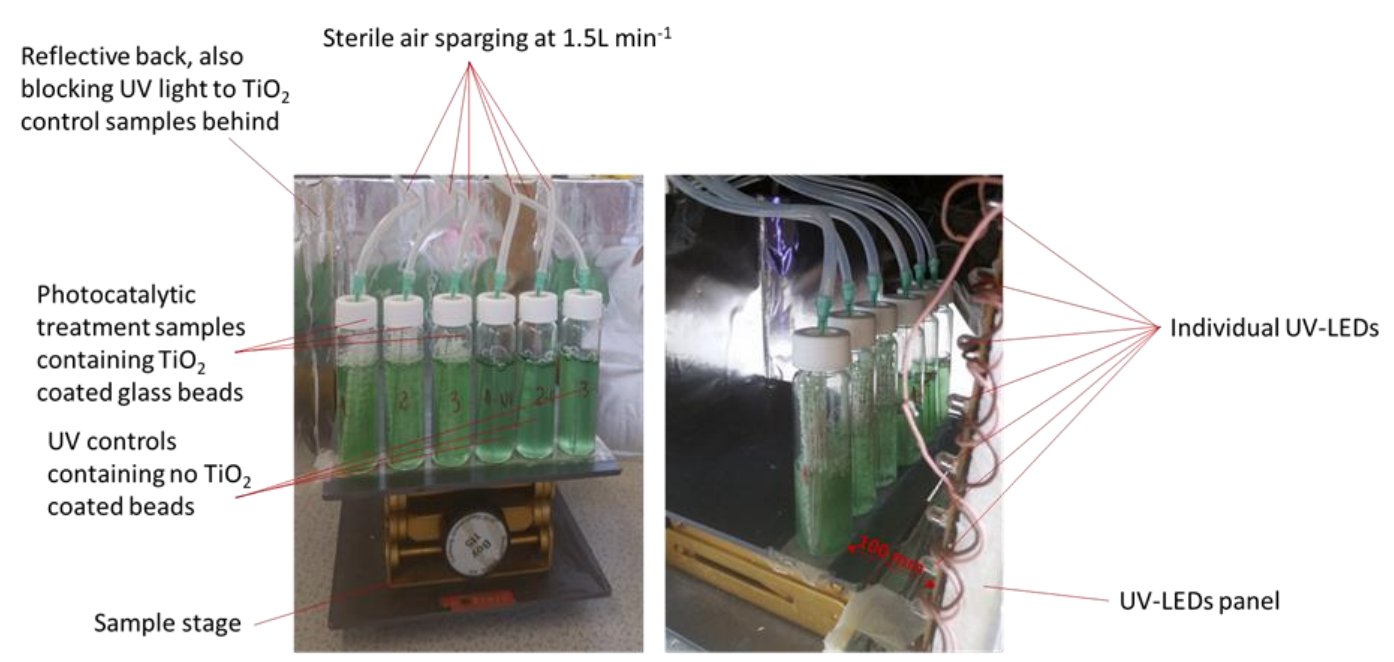

Figure 1: A) Schematic diagram of the UV-LED photocatalytic experimental design (topdown view). 1- air pump, 2- air distribution hub to achieve equal air pressure across all samples, 3- silicone tubing of equal length, 4- $\mathrm{TiO}_{2} / \mathrm{UV}$ treatment samples in triplicate, 5UV control samples in triplicate, 6- UV-LED panel with 90 UV-LEDs (365 nm, $67.5 \mathrm{~mW}$ total output) in 9 rows of 10 LEDs; output at $100 \mathrm{~mm} 2.6 \mathrm{~mW} \mathrm{~s}^{-1}, 7$ - reflective surface; also blocking UV irradiation from LED panel to $\mathrm{TiO}_{2}$-controls (8), 8- $\mathrm{TiO}_{2}$-control samples in triplicate, 9- silicone tubing. B) Photographic representation of the reactor and the $\mathrm{TiO}_{2} /$ UV and UV control samples.

\subsection{Sample analysis}

\subsubsection{Cell enumeration and sample pre-treatment}

For cell enumeration, cell volume determination, and determination of the average cell diameter of $M$. aeruginosa PCC7813, $0.1 \mathrm{~mL}$ of each sample was diluted in $20 \mathrm{~mL}$ of Isoton II diluent and analysed by a Multisizer (Beckman 
207 Coulter, USA). For this a $50 \mu \mathrm{m}$ aperture was used, allowing the determination

208

209

210

211

212

213

214

215

216

217

218

219

220

221

222

223

224

225

226

227

228

229

230

231 of particles sized between 1 and $30 \mu \mathrm{m}$, particles ranging in size from 2.8 to 6.9 $\mu \mathrm{m}$ were considered intact cells based on published data of cell size ranges for M. aeruginosa (Harke et al., 2016; Komárek and Komárková, 2002). This cut-off had to be introduced to ensure that cell fragments smaller than $2.8 \mu \mathrm{m}$ are not considered cells which would artificially increase the cell densities. For microcystin analysis, the remaining $1 \mathrm{~mL}$ of each sample was centrifuged (13000 G) in microcentrifuge tube $(1.5 \mathrm{~mL})$ for $10 \mathrm{~min}$ to separate cells and medium. The supernatant was evaporated to dryness on an EZ-II Evaporator (Genevac, United Kingdom). The cell pellet was stored at $-20^{\circ} \mathrm{C}$ until further processing. Prior to analysis, aqueous methanol ( $80 \%$ ) was added to the cell pellets which were subsequently placed in a dispersive extractor for 5 minutes at $2500 \mathrm{rpm}$ and then centrifuged (13000 G). The supernatant was analysed to determine intracellular toxin. The dried extracellular component was also resuspended in aqueous methanol $(80 \%, 150 \mu \mathrm{L})$, vortexed and centrifuged (13000 G). The intra- and extracellular microcystins were analysed by HPLC.

\subsubsection{High performance liquid chromatography analysis of microcystins}

Chromatographic separation of microcystin analogues was carried out using a 2965 separation module with a Symmetry C18 column $(2.1 \times 150$ mm, $5 \mu \mathrm{m}$ particle size) and a 2996 photodiode array (PDA) detector. Mobile phases were ultrapure water (18.2 $\mathrm{M} \Omega$ ) and acetonitrile both with $0.05 \%$ trifluoroacetic acid. Separation was achieved with a linear gradient from 35 to $70 \%$ organic phase over 25 min followed by an organic solvent wash (100\%) and re-establishment of starting conditions. Column temperature was $40^{\circ} \mathrm{C}$. Scanning range for the 
232 PDA was 200 to $400 \mathrm{~nm}$, with microcystins integrated at $238 \mathrm{~nm}$. The limit of quantification of this method was $5 \mathrm{ng} \mathrm{mL}^{-1}$.

\subsubsection{Statistical analysis}

All values shown are mean of triplicate treatments with error of one standard deviation. For statistical significance testing results were analyzed using one-way ANOVA. The significance level was set to $p>0.05$ to identify significant differences between results.

\section{Results and Discussion}

\subsection{Photocatalytic removal of M. aeruginosa PCC7813}

The removal of $M$. aeruginosa PCC7813 in a photocatalytic reactor with $\mathrm{TiO}_{2}$ coated porous glass beads and UV-LED irradiation was initially investigated. Over the course of seven days treatment the cell concentration of $M$. aeruginosa PCC7813 increased significantly in both controls, UV with no catalyst and no UV irradiation ( $p<0.05$ each), achieving 32 and $34 \times 10^{6}$ cells $\mathrm{mL}^{-1}$ respectively, representing a per cent increase of 213 and $226 \%$. There was no statistical difference between the UV- and the $\mathrm{TiO}_{2}$-controls $(p>0.05)$. No effect of the UV only control would be expected as the UV light emitted by the UV-LED is comparatively low in energy at $2.6 \mathrm{~mW} \mathrm{~s}^{-1}$ and the emitted wavelength is insufficient to be germicidal (germicidal wavelength $<254 \mathrm{~nm}$; Ou et al., 2012). On the other hand, in the treatment samples the initial cell concentration (15 $\mathrm{x}$ $10^{6}$ cells $\mathrm{mL}^{-1}$ ) was significantly reduced to $10 \times 10^{6}$ cells $\mathrm{mL}^{-1}(35 \%$, $p=0.00004$ ) when compared to the $\mathrm{TiO}_{2}$-control (figure 2). The biovolume of the M. aeruginosa PCC7813 culture also decreased over the course of the experiment ( $66 \%$ of the $\mathrm{TiO}_{2}-$ control), which corresponds to and corroborates 
258 the observed decrease in cell density. There was no statistical difference

259 between the two controls with respect to the cell volume $(p>0.05)$. The diameter

260 of the intact cells $(2.8-6.5 \mu \mathrm{m})$ did not significantly change $(p>0.05)$ from either

261 the initial cell size at time zero or after seven days treatment when compared to

262 either control (UV with catalyst and no UV irradiation). This indicates that the

263 treatment fragmented the cells into particles smaller than $2.8 \mu \mathrm{m}$ rather than

264 affect the cell diameter since the mean cell diameter did not change. Cell

265 fragmentation during photocatalytic treatment was also observed by Wang et al.

266 (2017) where M. aeruginosa (strain 913 from Wuhan Institute of Hydrobiology)

267 cells were treated with floating, expanded perlite particles that were coated with

268 F-Ce doped $\mathrm{TiO}_{2}$. 

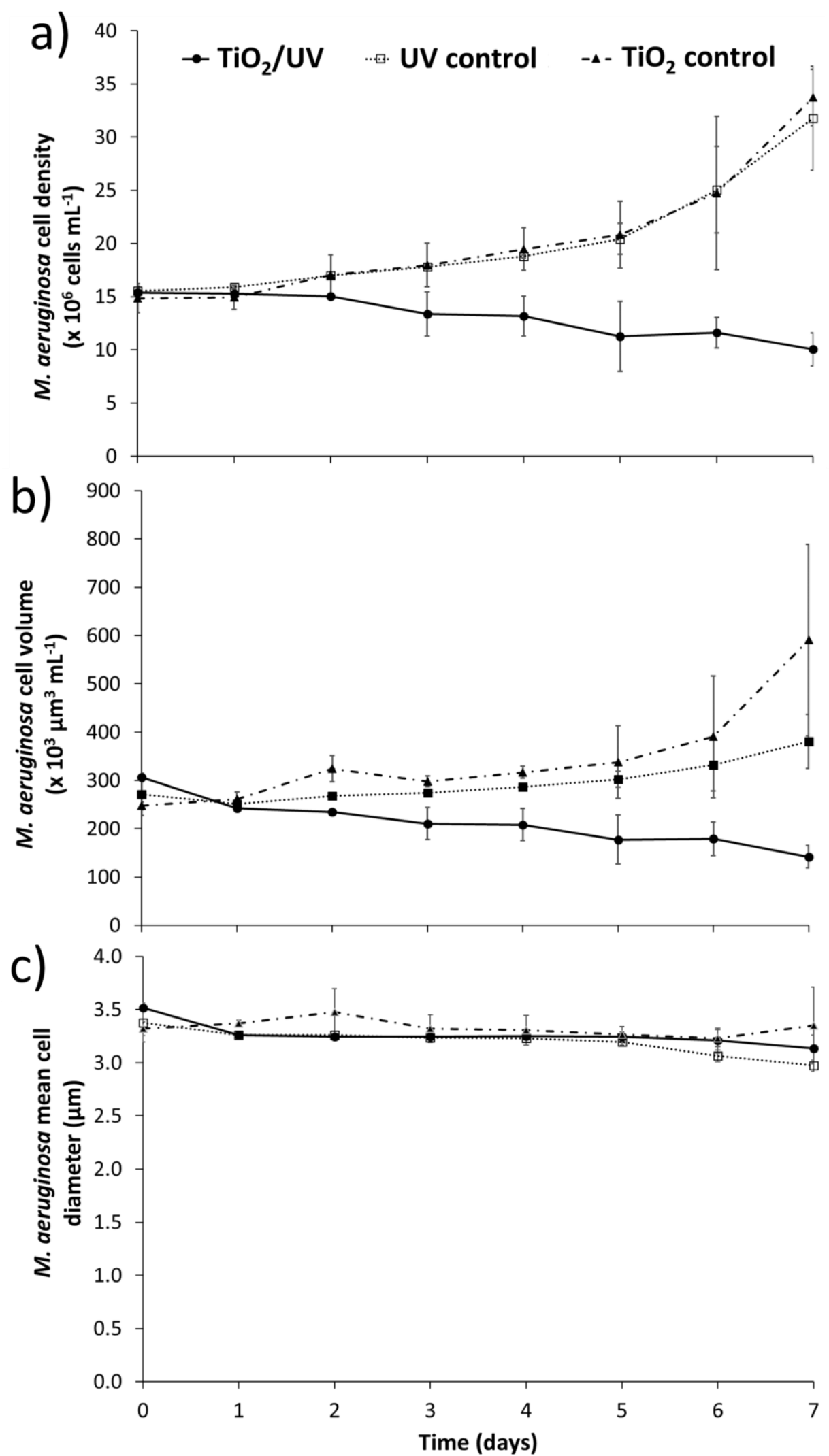

272 Figure 2: a) Removal of $M$. aeruginosa PCC7813 cells by photocatalysis using $\mathrm{TiO}_{2}$ coated porous glass beads over a seven-day period under $2.8 \mu \mathrm{mol}$ photons $\mathrm{m}^{-2} \mathrm{~s}^{-1}$ at $365 \mathrm{~nm}\left(2.6 \mathrm{~mW} \mathrm{~s}^{-1}\right)$ at $100 \mathrm{~mm}$ distance, as well as the effect of the treatment on $M$. aeruginosa PCC7813 b) cell volume, and c) mean cell diameter. ( $n=3$, Error $=1 \mathrm{SD})$ 
276 From $48 \mathrm{~h}$ onwards, a decline in cell density was observed for the treatment with

$277 \mathrm{TiO}_{2} / \mathrm{UV}$ (figure 2a). Other studies have reported the inhibition of $M$. aeruginosa

278 growth by $\mathrm{TiO}_{2}$ photocatalysis in one hour (Liao et al., 2009; Pinho et al., 2015), however, there are marked differences in the application of the $\mathrm{TiO}_{2}$ photocatalysis in terms of light source, M. aeruginosa strain, and presentation of $\mathrm{TiO}_{2}$. The UV-LED panel employed in the current investigation had a total output of $67.5 \mathrm{~mW}$ (with each individual LED having an output of $750 \mu \mathrm{W}$, and the panel having a total of 90 LEDs) providing a very low energy input into the system. By comparison Pinho et al. (2015), who investigated the removal of $M$. aeruginosa LEGE 91094 (IZANCY-A2) with particulate $\mathrm{TiO}_{2}$, used simulated solar irradiation at a UV equivalent of $44 \mathrm{~W} \mathrm{~m}^{-2}$, and Liao et al. (2009), who investigated the effect of silver-doped $\mathrm{TiO}_{2}$ particulates on an unspecified $M$. aeruginosa strain, used a UV-C lamp with $4 \mathrm{~W}$ output at $253.7 \mathrm{~nm}$. The UV-LEDs (67.5 $\mathrm{mW}$ ) deployed in the current investigation use almost sixty times less technology. A particular advantage of the current system is the use of immobilized $\mathrm{TiO}_{2}$. While the reactive surface area is markedly reduced compared to particulate catalyst systems, immobilized catalyst offers a much more facile post-treatment separation of catalyst and water compared to (nano)particulate $\mathrm{TiO}_{2}$. In addition, most of these other studies which investigated the inhibition of M. aeruginosa by $\mathrm{TiO}_{2}$ photocatalysis, used modified $\mathrm{TiO}_{2}$ composite materials. 
Ce-doped $\mathrm{TiO}_{2}$ further increasing the photocatalytic activity compared to $\mathrm{TiO}_{2}$ alone. The doping of $\mathrm{TiO}_{2}$ offers the advantage of shifting reactivity into the visible spectrum, however, this has to be weighed against the cost of the doping material and the complexity of preparation. Additionally, the intended application has to be considered. The current design is aimed at continuous operation within a reservoir to ease the burden on the water treatment process within a treatment plant. Thus, materials used need to be plentiful, economically affordable, and easy to obtain, which is not the case when doping with, for example, noble metals.

The UV irradiation ( $365 \mathrm{~nm}$ ) alone had no observable effect on the cell number, cell volume, or cell diameter (figure 2), which was what might have been expected since antimicrobial UV treatments tend to employ irradiance in the UVC spectrum of a wavelength of $260 \mathrm{~nm}$ and below (Wolfe, 1990). This was demonstrated in the Liao et al. (2009) study where approximately $12 \%$ difference in the chlorophyll a content between an untreated and the UV(C) controls was observed.

\subsection{Photocatalytic removal of four microcystin congeners}

The strain of M. aeruginosa PCC7813 used in the current investigation produces four main microcystin congeners (MC-LR, -LY, -LW, and -LF). During the photocatalysis of $M$. aeruginosa PCC7813 both the intracellular (figure 3) and extracellular (figure 4) microcystin concentrations were monitored. As microcystins are usually encountered in the intracellular space until cell integrity is compromised and the intracellular toxins leak into the surrounding water, monitoring the intracellular concentration during photocatalysis can be used as a proxy measurement of cell integrity. The distribution of the four congeners at 
the start of the experiment was MC-LR 58\%, MC-LY 9\%, MC-LW 14\%, and MC-

LF $19 \%$ of the total intracellular microcystin concentration. A significant $(p=0.0009$ to 0.045$)$ decrease of intracellular toxin concentration was observed for all four microcystin congeners over the course of seven days (figure 3) during photocatalytic treatment. Combined intracellular microcystin content decreased by $49 \%$ from 0.69 to $0.35 \mu \mathrm{g} \mathrm{mL}^{-1}$. Individually the concentrations for MC-LR, -LY, -LW, and -LF decreased by $53,34,60$, and $54 \%$ respectively from the initial concentration present in the cells. The profile of different intracellular microcystin variants at the end of the seven-day experiment remained largely unchanged, with MC-LR remaining the main congener produced (54\%), followed by MC-LF (23\%) and MC-LY and MC-LW (11\% each). There was no statistical difference viz the intracellular toxin concentration in either of the two controls ( $p>0.05)$. Compared to the $\mathrm{TiO}_{2}$ and UV with no catalyst controls the concentration of the total intracellular microcystin in the treated samples was reduced by $67 \%$ with individual concentrations for MC-LR, -LY, -LW, and -LF decreased by $74,50,68$, and $71 \%$ respectively. It is predicted that decrease in cell density and toxins concentration would continue and be maintained at a low level if this treatment system is used in-situ in a reservoir. 

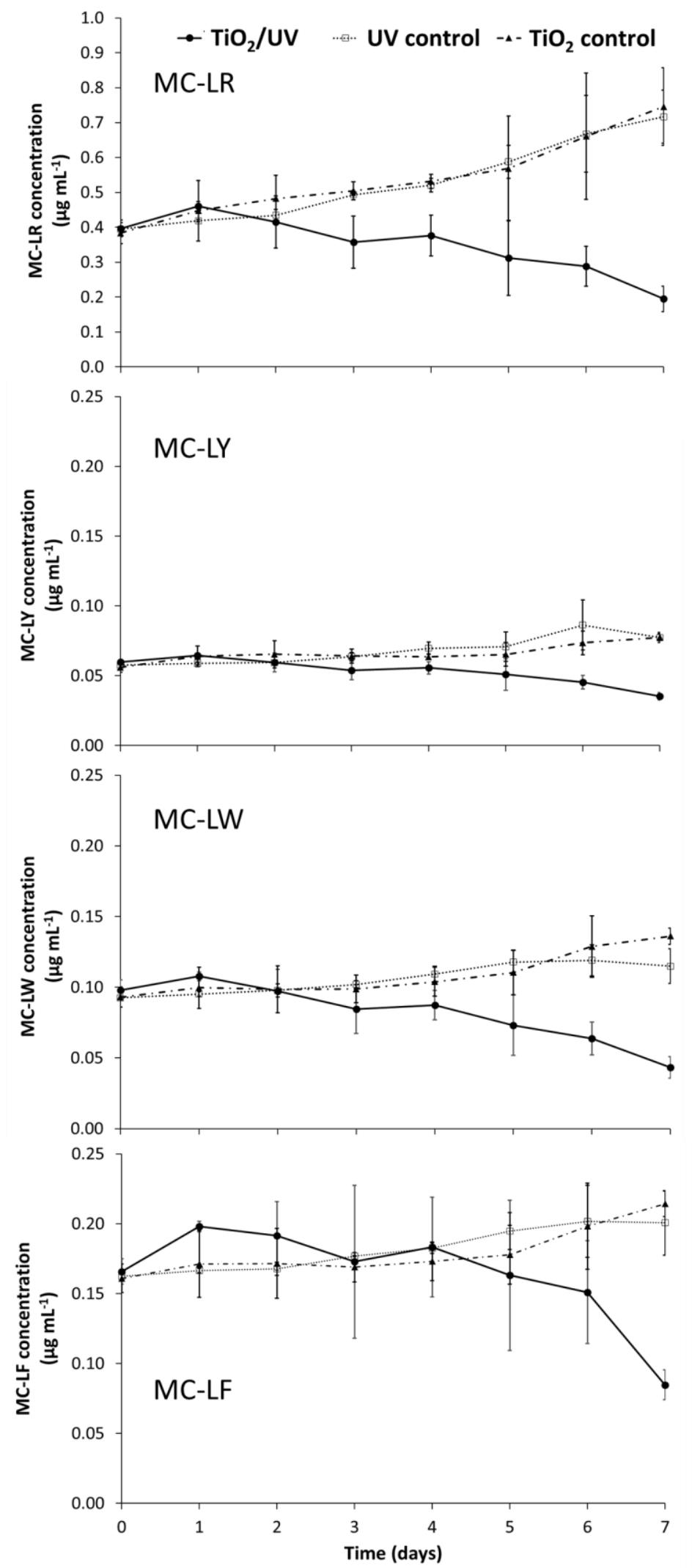
347 Figure 3: Removal of the four main intracellular microcystin analogues (MC-LR, MC-LY,
348 MC-LW, MC-LF) produced by M. aeruginosa PCC7813 during a seven-day photocatalytic treatment with $\mathrm{TiO}_{2}$ coated porous foamed recycled glass beads and UV-LED provided UV irradiation at $2.8 \mu \mathrm{mol}$ photons $\mathrm{m}^{-2} \mathrm{~s}^{-1}$ at $365 \mathrm{~nm}\left(2.6 \mathrm{~mW} \mathrm{~s}^{-1}\right)$ at a distance of $100 \mathrm{~mm}$. $(n=3$, Error $=1 \mathrm{SD})$ 
For most of the congeners the amount of toxin per cell decreased (table 1 ), which is indicative that some of the cells detected by the particle counter were damaged, but had not yet completely fragmented. Zilliges and co-workers (2011) have observed that intracellular microcystins concentrations decrease as a response to oxidative stress. In their study Zilliges et al. (2011) were able to observe intracellular microcystins bind to intracellular proteins in the presence of hydrogen peroxide $\left(0.34 \mathrm{mg} \mathrm{L}^{-1}\right)$. Hydrogen peroxide is a strong oxidizing agent and under UV irradiation hydrogen peroxide can lead to the creation of hydroxyl radicals, an even stronger oxidizing agent. Thus, the oxidative stress response of M. aeruginosa exposed to hydrogen peroxide may be comparable to the stress response to $\mathrm{TiO}_{2}$ photocatalysis (where hydroxyl and superoxide radicals are created), indicating that the decrease in intracellular microcystin concentrations could also be caused by microcystins binding to intracellular proteins although this would require further investigation.

Table 1: Reduction of intracellular microcystin congener concentration in $M$. aeruginosa PCC7813 after seven days of treatment in a photocatalytic reactor under UV-LED irradiation (at $2.8 \mu \mathrm{mol}$ photons $\mathrm{m}^{-2} \mathrm{~s}^{-1}$ at $365 \mathrm{~nm}\left(2.6 \mathrm{~mW} \mathrm{~s}^{-1}\right)$ ) at $100 \mathrm{~mm}$ distance in the presence of $\mathrm{TiO}_{2}$ coated porous glass beads. ( $n=3$, Error=1SD).

\begin{tabular}{|c|c|c|c|}
\hline MC congener & Time $0\left(\mathrm{fg} \mathrm{cell}^{-1}\right)$ & Time $7 \mathrm{~d}\left(\mathrm{fg} \mathrm{cell}^{-1}\right)$ & Per cent reduction \\
\hline MC-LR & $25.8 \pm 2$ & $19.4 \pm 2$ & $25^{*}$ \\
\hline MC-LY & $3.8 \pm 0.1$ & $3.5 \pm 0.4$ & 8 \\
\hline MC-LW & $6.4 \pm 0.4$ & $4.3 \pm 0.6$ & $32^{*}$ \\
\hline MC-LF & $10.8 \pm 0.7$ & $8.5 \pm 0.8$ & $21^{*}$ \\
\hline
\end{tabular}

*difference significant $(p>0.05)$

When the cell integrity of microcystin-producing cyanobacteria is compromised by oxidative processes, the intracellular organic material leaks into the surrounding water, including any microcystins (Daly et al., 2007). Therefore, it is important that water treatment systems either avoid compromising cell integrity or, failing that, the system should also be able to remove microcystins that are 
379 released into the water. Failing to remove the dissolved organic matter,

380 including microcystins, acerbates the challenges faced by water treatment

381 processes, as conventional water treatment is more suited to the removal of

382 particulate and colloidal than dissolved components (Chow et al., 1999; Li et al.,

383 2012). In the current investigation, extracellular concentrations of the four main

384 microcystin congeners produced by M. aeruginosa PCC7813 were also monitored

385 (figure 4).

386

387

388 

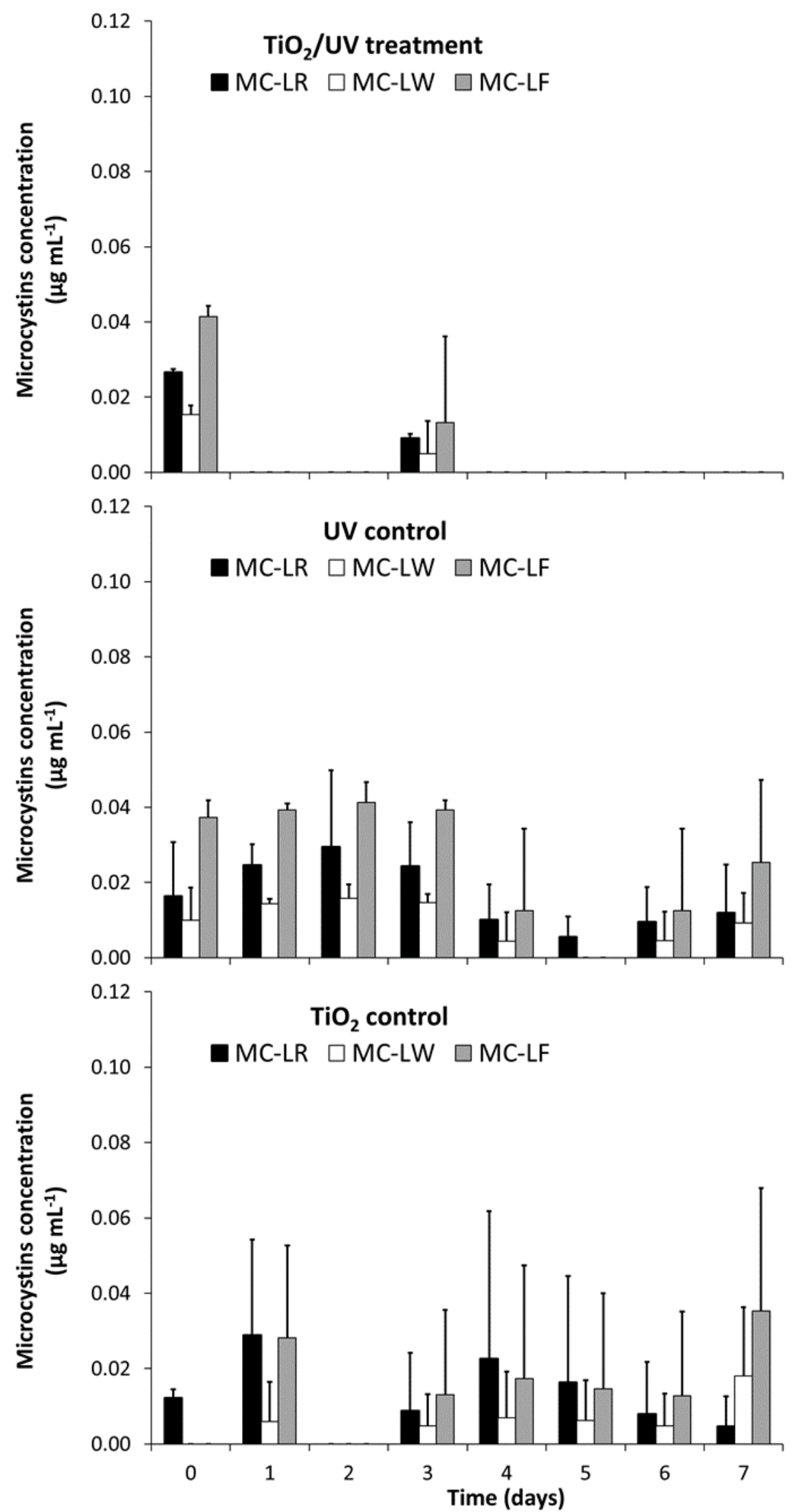

Figure 4: Extracellular microcystins (MC-LR, MC-LW, MC-LF) produced by M. aeruginosa PCC7813 during a seven-day photocatalytic treatment with $\mathrm{TiO}_{2}$ coated porous glass beads and UV-LED provided UV irradiation at $2.8 \mu \mathrm{mol}$ photons $\mathrm{m}^{-2} \mathrm{~s}^{-1}$ at $365 \mathrm{~nm}(2.6$ $\left.\mathrm{mW} \mathrm{s}^{-1}\right)$ at $100 \mathrm{~mm}$ distance. $(n=3$, Error $=1 \mathrm{SD})$ 
394 At the start of the experiment, relatively low concentrations $\left(0.02-0.04 \mu \mathrm{g} \mathrm{mL}^{-1}\right)$

395 of extracellular MC-LR, MC-LW, and MC-LF were detected, while no extracellular MC-LY was detected. Over the course of seven-day photocatalytic treatment, the extracellular microcystin concentrations remained low, not exceeding $0.05 \mu \mathrm{g}$ $\mathrm{mL}^{-1}$ in the treated samples, and were completely undetectable after day four of the $\mathrm{UV} / \mathrm{TiO}_{2}$ treatment. As the intracellular microcystins concentrations decrease due to loss of structural integrity of the cyanobacterial cells, extracellular toxin concentrations should increase, however this was not observed in the photocatalytically treated samples. Instead the intracellular microcystins were photocatalytically decomposed once they were released into the water. The efficacy of photocatalytic removal of dissolved microcystins has been demonstrated previously (Gunaratne et al., 2020; Lawton et al., 2003; Liu et al., 2009; Pestana et al., 2015). The decreased microcystin concentrations in the $\mathrm{TiO}_{2}$-control compared to the UV only control can be explained with adsorption of the microcystin congeners onto the surface of the $\mathrm{TiO}_{2}$ layer on the glass beads, as previously observed (Pestana et al., 2015). The sum of the intracellular and extracellular microcystin concentrations of the $\mathrm{TiO}_{2}$-control represents the total microcystin. Comparing this to the total microcystins of the photocatalytically treated samples allows the determination of the individual removal of the different microcystin congeners (table 2). 
Table 2: Reduction of total microcystins (intra- and extracellular) produced by $M$. aeruginosa PCC7813 after seven days of treatment in a photocatalytic reactor under UVLED irradiation $\left(2.8 \mu \mathrm{mol}\right.$ photons $\mathrm{m}^{-2} \mathrm{~s}^{-1}$ at $\left.365 \mathrm{~nm}\left(2.6 \mathrm{~mW} \mathrm{~s}^{-1}\right)\right)$ at $100 \mathrm{~mm}$ distance

\begin{tabular}{|c|c|c|c|c|}
\hline MC congener & $\begin{array}{c}\text { Mean total } \\
\text { microcystins } \\
\mathrm{TiO}_{2} \text { control } \\
\left(\mu \mathrm{mL}^{-1}\right)\end{array}$ & $\begin{array}{c}\text { Mean total } \\
\text { microcystins } \\
\text { photocatalytic } \\
\text { treatment } \\
\left(\mu \mathrm{mL}^{-1}\right)\end{array}$ & $\begin{array}{c}\text { Mean } \Delta \text { total } \\
\text { microcystins } \\
\text { time } 7 \mathrm{~d} \\
\left(\mu \mathrm{g} \mathrm{mL}^{-1}\right)\end{array}$ & $\begin{array}{c}\text { Mean } \\
\text { per cent } \\
\text { reduction } \\
\text { total } \\
\text { microcystins }\end{array}$ \\
\hline MC-LR & $0.79 \pm 0.04$ & $0.19 \pm 0.04$ & $0.6 \pm 0.07$ & $76 \pm 6$ \\
\hline MC-LY & $0.08 \pm 0.01$ & $0.04 \pm 0.01$ & $0.04 \pm 0.01$ & $55 \pm 3$ \\
\hline MC-LW & $0.15 \pm 0.02$ & $0.04 \pm 0.01$ & $0.12 \pm 0.01$ & $72 \pm 2$ \\
\hline MC-LF & $0.25 \pm 0.03$ & $0.08 \pm 0.01$ & $0.17 \pm 0.03$ & $66 \pm 5$ \\
\hline Combined & 1.28 & 0.35 & 0.93 & 73 \\
\hline
\end{tabular}

In the control samples (UV with no catalyst and $\mathrm{TiO}_{2}$ with no UV) there were no cell-disrupting processes occurring which would lead to the liberation of microcystins. Thus, as expected, the extracellular microcystins concentrations (MC-LR, -LW, -LF) remained relatively consistent in both control samples over the course of seven days. Lack of cellular disruption is evidenced by the increase in cell numbers over the course of the seven days (figure 2) and intracellular microcystin concentrations (figure 3 ) in the $\mathrm{TiO}_{2}$-control. The doubling rate of $M$. aeruginosa $\mathrm{PCC} 7813$ in the $\mathrm{TiO}_{2}$-control is approximately seven days (from $1.5 \times 10^{6}$ at time 0 to $3.4 \times 10^{6}$ cells $\mathrm{mL}^{-1}$ at time $7 \mathrm{~d}$ ). Wilson and co-workers (2006) report the average doubling time for environmental isolates of $M$. aeruginosa cultured in BG-11 medium as 2.8 days. In the current study $M$. aeruginosa PCC7813 was placed in artificial fresh water which contained none of the main nutrients required for growth, which can explain the slower doubling rate. Another factor that will affect the growth rate of $M$. aeruginosa is the initial inoculation cell density. In the current study initial cell density was $15 \times 10^{6}$ cells $\mathrm{mL}^{-1}$ in $30 \mathrm{~mL}$, which represents a very high inoculation cell density. In a laboratory study Dunn and Manoylov (2016) have demonstrated that $M$. 
initial inoculation cell density compared to a lower $\left(1 \times 10^{5}\right.$ cells $\left.\mathrm{mL}^{-1}\right)$ one in Bolds medium under laboratory conditions. No extracellular MC-LY was detected over the entire experimental period in neither the treatment samples or controls. This can be explained by the low intracellular concentrations of MC-LY $\left(0.06 \mu \mathrm{gL}^{-1}\right)$ present.

449

450

451

\section{Conclusions}

In the current study we have demonstrated that a simple photocatalytic system of recycled, $\mathrm{TiO}_{2}$ coated, porous, foamed glass beads with low level UV irradiation supplied by UV emitting LEDs can successfully inhibit cyanobacterial growth and eliminate released microcystins. The design of the treatment system is readily scalable. The housing of the beads can be increased in size to contain more $\mathrm{TiO}_{2}$-coated beads and the application of waterproof UV-LEDs in long strips attached to the side of the bead housing would facilitate the required UV irradiation. These LEDs may be powered by integrated floating solar panels that would provide a self-contained and sustainable treatment system. The proposed treatment system:

- is energy efficient due to the use of UV emitting LEDs requiring a lower energy in-put compared to conventional bulb light sources ( $\mathrm{mW}$ power input compared to $\mathrm{W}$ )

- could be powered in situ by photovoltaic cells to further increase the energy efficiency

- does not exacerbate the treatment challenge of, especially dissolved, cyanobacterial secondary metabolite and intracellular organic material by photocatalytically removing intracellular toxins 
- represents a "green" treatment option through the use of recycled materials, catalyst, and low-energy LEDs (which could be further enhanced by the application of photovoltaic cells).

\section{Acknowledgements}

The authors would like to acknowledge the Engineering and Physical Sciences Research Council (EPSRC) for funding this research [EP/P029280/1]. As per EPSRC requirements, the data will be made publicly available on the Robert Gordon University's repository, OpenAIR@RGU. Len Montgomery is appreciated for proof-reading the manuscript.

\section{References}

Akkanen, J., Kukkonen, J.V.K., 2003. Measuring the bioavailability of two hydrophobic organic compounds in the presence of dissolved organic matter. Environ. Toxicol. Chem. 22, 518-524. https://doi.org/10.1897/15515028(2003)022<0518:MTBOTH>2.0.CO;2

Bishop, W.M., Lynch, C.L., Willis, B.E., Cope, W.G., 2017. Copper-Based Aquatic Algaecide Adsorption and Accumulation Kinetics: Influence of Exposure Concentration and Duration for Controlling the Cyanobacterium Lyngbya wollei. Bull. Environ. Contam. Toxicol. 99, 365-371. https://doi.org/10.1007/s00128-017-2134-2

Chow, C.W.K., Drikas, M., House, J., Burch, M.D., Velzeboer, R.M.A., 1999. The impact of conventional water treatment processes on cells of the cyanobacterium Microcystis aeruginosa. Water Res. 33, 3253-3262. https://doi.org/10.1016/S0043-1354(99)00051-2

Cornish, B.J.P., Lawton, L. A., Robertson, P.K.J., 2000. Hydrogen peroxide 
enhanced photocatalytic oxidation of microcystin-LR using titanium dioxide. Appl. Catal. B Environ. 25, 59-67. https://doi.org/10.1016/S0926$3373(99) 00121-6$

498

499

500

501

502

503

504

505

506

507

508

509

510

511

512

Daly, R.I., Ho, L., Brookes, J.D., 2007. Effect of chlorination on Microcystis aeruginosa cell integrity and subsequent microcystin release and degradation. Environ. Sci. Technol. 41, 4447-4453.

https://doi.org/10.1021/es070318s

De Julio, M., Fioravante, D.A., De Julio, T.S., Oroski, F.I., Graham, N.J.D., 2010. A methodology for optimising the removal of cyanobacteria cells from a brazilian eutrophic water. Brazilian J. Chem. Eng. 27, 113-126. https://doi.org/10.1590/S0104-66322010000100010

Drikas, M., Chow, C.W.K., House, J., Burch, M., 2001. Using coagulation, flocculation and settling to remove toxic cyanobacteria. J. Am. Water Work. Assoc. $100-111$.

Dunn, R.M., Manoylov, K.M., 2016. The Effects of Initial Cell Density on the Growth and Proliferation of the Potentially Toxic Cyanobacterium Microcystis aeruginosa. J. Environ. Prot. 07, 1210-1220. https://doi.org/10.4236/jep.2016.79108

Fagan, R., McCormack, D.E., Dionysiou, D.D., Pillai, S.C., 2016. A review of solar and visible light active $\mathrm{TiO} 2$ photocatalysis for treating bacteria, cyanotoxins, and contaminants of emerging concern. Mater. Sci. Semicond. Process 42(1), 2-14.

Fotiou, T., Triantis, T.M., Kaloudis, T., Pastrana-Martinez, L.M., Likodimos, V., Falaras, P., Silva, A.M.T., Hiskia, A., 2013. Photocatalytic degradation of microcystin-LR and off-odor compounds in water under UV-A and solar light with nanostructured photocatalyst based on reduced graphene oxide- $\mathrm{TiO}_{2}$ 
composite. Identification of intermediate products. Ind. Eng. Chem. Res. 52(39), 13991-14000.

García-Villada, L., Rico, M., Altamirano, M., Sánchez-Martín, L., López-Rodas, V., Costas, E., 2004. Occurrence of copper resistant mutants in the toxic cyanobacteria Microcystis aeruginosa: Characterisation and future implications in the use of copper sulphate as algaecide. Water Res. 38, 2207-2213. https://doi.org/10.1016/j.watres.2004.01.036

Grassian, V.H., O'Shaughnessy, P.T., Adamcakova-Dodd, A., Pettibone, J.M., Thorne, P.S., 2007. Inhalation exposure study of Titanium dioxide nanoparticles with a primary particle size of 2 to $5 \mathrm{~nm}$. Environ. Health Perspect. 115, 397-402. https://doi.org/10.1289/ehp.9469

Greenfield, D.I., Duquette, A., Goodson, A., Keppler, C.J., Williams, S.H., Brock, L.M., Stackley, K.D., White, D., Wilde, S.B., 2014. The Effects of Three Chemical Algaecides on Cell Numbers and Toxin Content of the Cyanobacteria Microcystis aeruginosa and Anabaenopsis sp. Environ. Manage. 54, 1110-1120. https://doi.org/10.1007/s00267-014-0339-2

Gunaratne, H.Q.N., Pestana, C.J., Skillen, N., Hui, J., Saravanan, S., Edwards, C., Irvine, J.T.S., Robertson, P.K.J., Lawton, L.A., 2020. 'All in one' photoreactor pod containing $\mathrm{TiO}_{2}$ coated glass beads and LEDs for continuous photocatalytic destruction of cyanotoxins in water. Environ. Sci. Water Res. Technol. 6, 945-950. https://doi.org/10.1039/c9ew00711c Harke, M.J., Steffen, M.M., Gobler, C.J., Otten, T.G., Wilhelm, S.W., Wood, S.A., Paerl, H.W., 2016. A review of the global ecology, genomics, and biogeography of the toxic cyanobacterium, Microcystis spp. Harmful Algae 54, 4-20. https://doi.org/10.1016/j.hal.2015.12.007

Heering, W., 2004. UV-sources - Basics, Properties and Applications. Int. Ultrav. 
Assoc. 6, 7-13.

Heinlaan, M., Ivask, A., Blinova, I., Dubourguier, H.C., Kahru, A., 2008. Toxicity of nanosized and bulk $\mathrm{ZnO}, \mathrm{CuO}$ and $\mathrm{TiO}_{2}$ to bacteria Vibrio fischeri and crustaceans Daphnia magna and Thamnocephalus platyurus. Chemosphere 71, 1308-1316. https://doi.org/10.1016/j.chemosphere.2007.11.047

Jančula, D., Maršálek, B., 2011. Critical review of actually available chemical compounds for prevention and management of cyanobacterial blooms. Chemosphere 85, 1415-1422. https://doi.org/10.1016/j.chemosphere.2011.08.036

Kinley, C.M., Hendrikse, M., Calomeni, A.J., Geer, T.D., Rodgers, J.H., 2018. Solar Photocatalysis Using Fixed-Film $\mathrm{TiO}_{2}$ for Microcystins from Colonial Microcystis aeruginosa. Water. Air. Soil Pollut. 229, 167. https://doi.org/10.1007/s11270-018-3791-4

Komárek, J., Komárková, J., 2002. Review of the European Microcystis morphospecies (Cyanoprokaryotes) from nature. Fottea 2, 1-24.

Lawton, L.A., Robertson, P.K.J., Cornish, B.J.P.A., Marr, I.L., Jaspars, M., 2003. Processes influencing surface interaction and photocatalytic destruction of microcystins on titanium dioxide photocatalysts. J. Catal. 213, 109-113. https://doi.org/10.1016/S0021-9517(02)00049-0

Li, L., Gao, N., Deng, Y., Yao, J., Zhang, K., 2012. Characterization of intracellular \& extracellular algae organic matters (AOM) of Microcystic aeruginosa and formation of AOM-associated disinfection byproducts and odor \& taste compounds. Water Res. 46, 1233-1240. https://doi.org/10.1016/j.watres.2011.12.026

Liao, X., Wang, X., Zhao, K., Zhou, M., 2009. Photocatalytic inhibition of cyanobacterial growth using silver-doped $\mathrm{TiO}_{2}$ under UV-C light. J. Wuhan 
Univ. Technol. Mater. Sci. Ed. 24, 402-408. https://doi.org/10.1007/s11595-009-3402-8

Liu, I., Lawton, L.A., Bahnemann, D.W., Liu, L., Proft, B., Robertson, P.K.J., 2009. The photocatalytic decomposition of microcystin-LR using selected titanium dioxide materials. Chemosphere 76, 549-553. https://doi.org/10.1016/j.chemosphere.2009.02.067

Liu, Y., Yang, S., Hong, J., Sun, C., 2007. Low-temperature preparation and microwave photocatalytic activity study of $\mathrm{TiO}_{2}$-mounted activated carbon. J. Hazard. Mater. 142, 208-215. https://doi.org/10.1016/j.jhazmat.2006.08.020

Mills, A., Wang, J., Crow, M., 2006. Photocatalytic oxidation of soot by $\mathrm{P} 25 \mathrm{TiO}_{2}$ films. Chemosphere 64, 1032-1035. https://doi.org/10.1016/j.chemosphere.2006.01.077

Ou, H., Gao, N., Deng, Y., Qiao, J., Wang, H., 2012. Immediate and long-term impacts of UV-C irradiation on photosynthetic capacity, survival and microcystin-LR release risk of Mircocystis aeruginosa. Water Res. 46, 12411250. https://doi.org/10.1016/j.watres.2011.12.025

Pelaez, M., de la Cruz, A.A., O'Shea, K., Falaras, P., Dionysiou, D.D., 2011. Effects of water parameters on the degradation of microcystin-LR under visible light-activated $\mathrm{TiO}_{2}$ photocatalyst. Water Res. 45, 3787-3796. https://doi.org/10.1016/j.watres.2011.04.036

Pestana, C.J., Edwards, C., Prabhu, R., Robertson, P.K.J., Lawton, L.A., 2015. Photocatalytic degradation of eleven microcystin variants and nodularin by $\mathrm{TiO}_{2}$ coated glass microspheres. J. Hazard. Mater. 300, 347-353. https://doi.org/10.1016/j.jhazmat.2015.07.016 Pinho, L.X., Azevedo, J., Brito, A., Santos, A., Tamagnini, P., Vilar, V.J.P., 
Vasconcelos, V.M., Boaventura, R.A.R., 2015. Effect of $\mathrm{TiO}_{2}$ photocatalysis

600

601

602

603

604

605

606

607

608

609

610

611

612

613

614

615

616

617

618

619

620

621

622

623

624

on the destruction of Microcystis aeruginosa cells and degradation of cyanotoxins microcystin-LR and cylindrospermopsin. Chem. Eng. J. 268, 144-152. https://doi.org/10.1016/j.cej.2014.12.111

Spoof, L., Catherine, A., 2017. Appendix 3, tables of microcystins and nodularins, in: Meriluoto, J., Spoof, L., Codd, G.A. (Eds.), Handbook of Cyanobacterial Monitoring and Cyanotoxin Analysis. John Wiley \& Sons, Chichester, UK, pp. 526-537.

Stanier, R.Y., Kunisawa, R., Mandel, M., Cohen-Bazire, G., 1971. Purification and properties of unicellular blue-green algae (order Chroococcales). Bacteriol. Rev. 35, 171-205. https://doi.org/10.1128/mmbr.35.2.171-205.1971

Varuni, P., Menon, S.N., Menon, G.I., 2017. Phototaxis as a Collective Phenomenon in Cyanobacterial Colonies. Sci. Rep. 7, 1-10. https://doi.org/10.1038/s41598-017-18160-w

Velzeboer, R., Drikas, M., Donati, C., Burch, M., Steffensen, D., 1995. Release of Geosmin by Anabaena circinalis Following Treatment with Aluminum Sulfate. Water Sci. Technol. 31, 187-194.

Wang, J., Zhou, G., Chen, C., Yu, H., Wang, T., Ma, Y., Jia, G., Gao, Y., Li, B., Sun, J., Li, Y., Jiao, F., Zhao, Y., Chai, Z., 2007. Acute toxicity and biodistribution of different sized titanium dioxide particles in mice after oral administration. Toxicol. Lett. 168, 176-185.

https://doi.org/10.1016/j.toxlet.2006.12.001

Wang, Xin, Wang, Xuejiang, Zhao, J., Song, J., Wang, J., Ma, R., Ma, J., 2017. Solar light-driven photocatalytic destruction of cyanobacteria by F-Ce$\mathrm{TiO}_{2}$ /expanded perlite floating composites. Chem. Eng. J. 320, 253-263. https://doi.org/10.1016/j.cej.2017.03.062 
WHO, 2017. Guidelines for Drinking-water Quality: fourth edition incorporating the first addendum. Geneva.

Wilson, A.E., Wilson, W.A., Hay, M.E., 2006. Intraspecific variation in growth and morphology of the bloom-forming cyanobacterium Microcystis aeruginosa. Appl. Environ. Microbiol. 72, 7386-7389. https://doi.org/10.1128/AEM.00834-06

Wolfe, R.L., 1990. Ultraviolet disinfection of potable water: Current technology and research needs. Environ. Sci. Technol. 24, 768-773. https://doi.org/10.1021/es00076a001

Zhu, X., Chang, Y., Chen, Y., 2010. Toxicity and bioaccumulation of $\mathrm{TiO}_{2}$ nanoparticle aggregates in Daphnia magna. Chemosphere 78, 209-215. https://doi.org/10.1016/j.chemosphere.2009.11.013

Zilliges, Y., Kehr, J.C., Meissner, S., Ishida, K., Mikkat, S., Hagemann, M., Kaplan, A., Börner, T., Dittmann, E., 2011. The cyanobacterial hepatotoxin microcystin binds to proteins and increases the fitness of Microcystis under oxidative stress conditions. PLoS One 6(3): e17615. https://doi.org/10.1371/journal.pone.0017615 